seems fortuitous that Vatican II assigned the laity a somewhat "secondary" role - to be good Christians in the secular realm. We must understand that this secular realm constitutes the frontier where the Christian faith will be tested. It is the realm where the Christian faith will receive new understanding in the light of new challenges and new opportunities. Within such perspectives, it seems that the ecclesia docens, as the authority which is called to preserve the traditional truth of its doctrine, becomes more and more passive. One comes to expect creativity, newness, and vitality to be provided by the laity who as the living blood and breath of the Church respond to the secular realm assigned to them. Somehow, this seems to be more and more the case in those countries where the laity have taken their responsibility seriously and are now challenging the hierarchy to catch up with development and growth.

Upon reading Coulson's account of Newman's brief period as editor of Rambler one is dismayed by the incredible hardness of heart he encountered on the part of the English Catholic hierarchy. So often in history the great spirituality of outstanding Christians finds major opposition from within their Church. Great women and men, of course, transcend this resistance. But we should try to appreciate all the suffering inflicted on such a man as Newman. Happy for him, he found great recognition and vindication in his elevation to Cardinal. But that does not happen often. Such a good ending seems possible only in Hollywood movies, which are lately reluctant to produce happy endings. The great Pierre Teilhard De Chardin never saw the day when his thoughts were celebrated by Catholic theology. Sadly he died rather lonely under the shadow of the Church's disapproval.

The memorial of Newman's elevation to Cardinal should be a celebration of justice having found a way to liberate a victim from prejudice, rejection, and suspicion.

-WILLIAM P. FROST

\title{
MUSIC OF THE SPHERES
}

It was a lazy day in April when we arrived at the office, perfunctorily raised the lid of our old roll-top desk, and began shuffling through the morning's mail. A glossy brochure caught our eye. "Yoga Ranch, in pastoral Prairie Dog Village, South Dakota. A quiet place away from the distractions of our gimmick-ridden society, our fast food counters; far, far away from the numbing sounds of electronic gadgetry and the din of the gasoline combustion engine. Yoga Ranch offers seminars on

The Metaphysics of Digestion

Aquarian Divination 
Esoteric Chanting (in the specially prepared caves in nearby Dry Gulch)

Femininity and Destiny

Mastering the Serpent Power

With Multimedia presentations on

Spiritual Transformation

Soul Migration

Techniques of Ecstasy

Psychic Wholeness

-each integrated with an expertly tailored program of experiential exercises."

It seemed just the thing for us, after a long and dreary winter. We unhesitatingly filled in the application coupon at the bottom, and noted the fee for the two-week retreat: a mere $\$ 999$, payable by Bank Americard, VISA or Master Charge. At last, promise of relief from our over-civilized world. We glanced above the coupon at a section headed "What to Bring." They recommended lots of blank tapes to record the seminar sessions on your portable Panasonic, and a good strong flashlight for finding your way to the rustic facilities after dark. Otherwise, they reassured us, all we needed by way of clothing was a pair of comfortable shoes, light, loose-fitting attire, and our guitar.

It had not struck us till that very moment how far we had been left behind by the youth culture. We did not even own a guitar! Suddenly we felt spiritually naked. We felt that for the first time we could fully comprehend how Adam and Eve must have felt. We experienced a renewed faith in the folks at Yoga Ranch: we had barely finished browsing their small brochure, and already we had eaten of the fruit of the twentieth century Tree of Knowing.

We hastily slammed down the lid on our desk and made our way out between the musty shelves adjoining our small cubicle at the back of the third floor of the Argosy Book Shop, crossed Lexington Avenue, and went in to Bloomingdale's.

"Guitars?" we asked.

"Fourth Floor, Men's Wear."

We slipped into a glass and bronze elevator door just as it was closing.

"Yes sir, may we help you?"

It was Ananda T. Burbank! We recalled our pleasant chat when he was working for the Vanitas Press, but he did not seem anxious to discuss the recent past.

"I was looking for something in a guitar."

"Of course. We have some very nice ones, just in from Milan, in a modest and serviceable black or charcoal grey." 
"I had something more casual in mind."

"A brown corduroy, then."

"It's for a meditation camp in South Dakota_-"

"Not Yoga Camp?" His eyes brightened. "I was there three summers ago. What a beautiful setting! I was invited to do a two-week seminar on 'The Inner World of the Native American." We read all of Weston LaBarre's writings, saw slides, and made daily visits to the Nachiketas Reservation-it's just five miles away, you know. They taught us how to do the Otter Dance, and on the night of the August moon we were invited to participate in the annual Rite of the Blissful Mushroom. Oh, it was a memorable summer."

A. T.'s eyes glistened as they did when we first met him, in his college teaching days at Upper Nyack; but he quickly reminded himself that he was now working for Bloomingdale's.

"What you'll want, then, is our denim guitar with white stitching and Madras patches."

He deftly extracted one from the rack that was just our size, and then fitted us for a matching set of beads and a black turtleneck.

As we were waiting to have the cashier feed our credit card through the computer, we spied a whole rack of shimmering, oddly shaped guitars.

"What are those over there?" we asked Ananda.

"Electric. Not at all suited to Yoga Ranch."

"How so?"

"Haven't you read the brochure?"

He began to assume that supercilious manner which is one of his less endearing qualities.

We took the brochure from our pocket and handed it to him.

"Here, read this paragraph," he said.

We read.

"Yoga Ranch is located on the former campsite of an old nineteenth century trading post. We have authentic log cabins and canvas teepees for our campers, a clear, fresh mountain stream for your morning dip, rich brown fields of organically grown food for our vegetarian tables, and such modern additions as a full sauna with massage facilities, and an exterior samadhi tank."

"What's an 'exterior samadhi tank'?" we asked.

"At the end of each day," Ananda explained, "as the sun begins to settle behind the South Dakota hills, all the campers slip into the samadhi pool, wearing their guitars. All have learned to play a certain chord which was discovered by the founder of the Ranch, Swami Somamuktananda. This chord, he said, was the sound that was made at the Creation, and is repeated each time the universe collapses into itself and is reborn out of the chaos every $8,640,000$ years. It signifies the 
harmony of the spheres. When the light of the evening star first appears, all the campers strike that chord on their guitars.

"A couple of years ago, on a warm July evening, unbeknownst to the Swami, one of the campers entered the pool with a brand new D'Aquisto guitar, plugged into the poolside lighting fixtures. There was a magnificent red sunset, twilight settled in, and Venus appeared in the western sky. Our camper switched on his guitar, and just as they all struck the mystic chord, out they all came, like rockets in the night sky. Many who were there that year still maintain that it was a hierophany, and will not listen to the more mundane explanation. The Swami himself was unconscious for seven days. When he regained his senses he quietly announced that he was returning to India, and would not return again. To this day, no one at the Ranch has heard from him. His disciples are carrying on as best they can."

We were about to board the M101 bus, newly outfitted in our dark turtleneck, beads, and denim guitar, but thought better of it, and hailed a cab. The little placard on the back seat indicated that the driver's name was Muscles Marinara.

"Where to, Mac?"

"To the stars," we wanted to reply, "to Mercury and Venus, to Jupiter or Mars." We felt that we were at last on the path to selfdiscovery; that we had at last joined the rush toward the fulfillment of human potential; that our life's pilgrimage was just beginning.

"Penn Station," we said. 